\title{
Axonal Projection, Input and Output Synapses, and Synaptic Physiology of Cajal-Retzius Cells in the Developing Rat Neocortex
}

\author{
Gabriele Radnikow, ${ }^{1}$ Dirk Feldmeyer, ${ }^{1}$ and Joachim Lübke ${ }^{2}$ \\ ${ }^{1}$ Max Planck Institute of Medical Research, Department for Cell Physiology, D-69120 Heidelberg, Germany, and \\ 2Department of Anatomy, Albert Ludwigs University Freiburg, D-79104 Freiburg, Germany
}

\begin{abstract}
Cajal-Retzius (CR) cells are among the earliest generated neurons and are thought to play a role in corticogenesis and early neuronal migration. However, the role of CR cells in an early cortical microcircuit is still rather unclear. We therefore have investigated the morphology and physiology of CR cells by using whole-cell patch-clamp recordings combined with intracellular biocytin filling in acute brain slices of postnatal day 5-11 rats. CR cells are characterized by a long horizontally oriented dendrite; the axonal collaterals form a dense horizontally oriented plexus in layer 1 and to a certain extent in layer $2 / 3$, projecting over $>2 \mathrm{~mm}$ of cortical surface. The bouton density is relatively high, and synaptic contacts are established preferentially with dendritic spines or shafts of excitatory neurons, presumably terminal tuft dendrites of pyramidal neurons. In turn, CR cells receive dense GABAergic and non-GABAergic input on somata, dendritic shafts, and spine-like appendages.
\end{abstract}

Extracellular stimulation in layer 1 could activate both GABAergic and glutamatergic synaptic inputs. The GABAergic response was blocked by the $\mathrm{GABA}_{\mathrm{A}}$ receptor antagonist bicuculline. The glutamatergic response was mediated solely by NMDA receptors and was highly sensitive to ifenprodil, indicating that it was mediated mainly via NR1/NR2B subunitcontaining receptors. NMDA EPSPs were apparent in $1 \mathrm{~mm}$ extracellular $\mathrm{Mg}^{2+}$, suggesting that this pure NMDA synapse is not silent functionally. Together, the long-range horizontal projection of the axon, the high density of synaptic boutons, and the functional synaptic input of CR cells suggest that they are an integral part of an early cortical network.

Key words: Cajal-Retzius cells; layer 1; neocortex; input and output synapses; long-range horizontal axons; synaptic physiology
Cajal-Retzius cells, originally described by Ramón y Cajal (1891) and Retzius (1893, 1894), are early generated neurons of the ventricular zone that migrate from their place of birth into the cortical preplate, also known as the early marginal zone (MarínPadilla, 1978; Luskin and Shatz, 1985) (for review, see Frotscher, 1998; Marín-Padilla, 1998). Because they are generated at the onset of corticogenesis at approximately embryonic day (E) 12-15 in rat, these neurons often have been considered as pioneer neurons (König and Marty, 1981; Luskin and Shatz, 1985; Bayer and Altman, 1990) (for review, see Meyer et al., 1998; Mienville, 1999). As the neocortex develops, the marginal zone becomes layer 1; subsequently, CR cells begin to disappear, in rat at approximately postnatal day 15 (P15) (Derer and Derer, 1990; Del Rio et al., 1996, 1997; Mienville and Pesold, 1999). The fate of CR cells is the subject of ongoing controversy, being attributed to cell death, to dilution in the developing neocortex, or to differentiation into other cortical cell types (Edmunds and Parnavelas, 1982; Parnavelas and Edmunds, 1983; Derer and Derer, 1990, 1992; Zecevic and Rakic, 2001) (for review, see MarínPadilla, 1998; Meyer et al., 1999; Mienville, 1999).

CR cells have been suggested to play a key role in the structural

Received Feb. 20, 2002; revised April 29, 2002; accepted May 2, 2002.

This work was supported by the Sonderforschungsbereich 488 (Teilprojekt D1 to D.F.), the Deutsche Forschungsgemeinschaft (Lu 593/3-1), and the Max Planck Society. We thank Professor M. Frotscher and Dr. K. Ceranik for critically reading this manuscript. We are also grateful to I. Dehof, B. Joch, S. Nestel, M. Kaiser, K. Puff, and M. Winter for excellent technical assistance.

Correspondence should be addressed to Dirk Feldmeyer, Max-Planck-Institut für Medizinische Forschung, Abteilung für Zellphysiologie, Jahnstrasse 29, D-69120 Heidelberg, Germany. E-mail: feldmeyr@mpimf-heidelberg.mpg.de.

Copyright (ㄷ) 2002 Society for Neuroscience 0270-6474/02/226908-12\$15.00/0 and functional organization of the neocortex, in particular in layer formation and the inside first-outside last patterning (Luskin and Shatz, 1985; Noctor et al., 1999, 2001) (for review, see Rakic and Caviness, 1995). It has been shown that the degeneration of CR cells in newborn animals results in a dramatic decrease in the number of radial glial cells and to their early transformation into astrocytes. Radial glia are thought to provide a scaffold along which neurons can migrate to their respective layers. As a consequence, CR cell degeneration interrupts cortical layer formation (Supèr et al., 2000). Together, these findings suggest an essential role of CR cells in corticogenesis.

However, the role of CR cells is still rather unknown and is subject to ongoing discussion (Derer and Derer, 1990, 1992; Verney and Derer, 1995; Del Rio et al., 1996, 1997; Supèr et al., 1998, 2000; Meyer et al., 2000; Perez-Garcia et al., 2001) (for review, see Frotscher, 1998; Marín-Padilla, 1998). A detailed knowledge of the input and output structures of CR cells is required to understand how $\mathrm{CR}$ cells may contribute to an early cortical microcircuitry. Here we investigated CR cells in the developing rat neocortex, in particular their axonal projection, their input-output relations, and synaptic physiology, by using whole-cell patch-clamp recordings combined with intracellular biocytin filling and subsequent electron microscopy. Our morphological findings, in particular the long-range horizontal projection, the input-output relations, and the synaptic physiology, suggest that CR cells are active elements in an early neuronal network.

\section{MATERIALS AND METHODS}

Preparation of acute brain slices. All experiments were performed in accordance with the animal welfare guidelines of the Max Planck Society 
and the University of Freiburg. Wistar rats (P5-P11) were anesthetized and then decapitated. Coronal slices $(350-400 \mu \mathrm{m}$ in thickness cut from the rostral surface) and parasagittal slices (right and left hemispheres separated, tissue fixed on the midline of the brain, cut from the lateral surface) were prepared with a vibrating microslicer (DTK-1000; Dosaka, Kyoto, Japan). Slices were incubated at room temperature $\left(20-23^{\circ} \mathrm{C}\right)$ for 30 min before recordings were made.

Solutions and drugs. Slices were superfused continuously with extracellular solution containing (in $\mathrm{mM}$ ): $125 \mathrm{NaCl}, 2.5 \mathrm{KCl}, 25$ glucose, 25 $\mathrm{NaHCO}_{3}, 1.25 \mathrm{NaH}_{2} \mathrm{PO}_{4}, 2 \mathrm{CaCl}_{2}$, and $1 \mathrm{MgCl}_{2}$ oxygenated with $95 \%$ $\mathrm{O}_{2} / 5 \% \mathrm{CO}_{2}$. In experiments to identify the evoked NMDA EPSC, $\mathrm{MgCl}_{2}$ was omitted from the bath solution. The intracellular pipette solution contained (in mM): $105 \mathrm{~K}$-gluconate, $30 \mathrm{KCl}, 10 \mathrm{HEPES}, 10$ phosphocreatine, 4 ATP-Mg, and 0.3 GTP (pH-adjusted to 7.3 with 300 $\mathrm{mOsm} \mathrm{KOH}$ ) and for some voltage-clamp experiments $105 \mathrm{Cs}$-gluconate, $30 \mathrm{CsCl}, 10 \mathrm{HEPES}, 10$ phosphocreatine, $4 \mathrm{ATP}-\mathrm{Mg}$, and $0.3 \mathrm{GTP}$ ( $\mathrm{pH}$-adjusted to 7.3 with $300 \mathrm{mOsm} \mathrm{CsOH}$ ). For morphological analysis $1-2 \mathrm{mg} / \mathrm{ml}$ biocytin (Fluka, Hamburg, Germany) was added routinely to the internal solution.

D-AP-5 (D(-)-2-amino-phosphonopentanoic acid), 7-chlorokynurenate, and NBQX (2,3-dioxo-6-nitro-1,2,3,4-tetrahydrobenzo[f]quinoxaline-7sulfonamide) were purchased from Tocris Cookson (Bristol, UK); bicuculline methiodide and ifenprodil were from Sigma-Aldrich (Deisenhofen, Germany).

Visual identification of $C R$ cells. Slices were placed in the recording chamber under an upright microscope (Axioskop; Zeiss, Göttingen, Germany). CR cells were identified visually at $40 \times$ magnification with the use of infrared-gradient contrast (IR-GC) microscopy by their location in cortical layer 1 , by the size and shape of their somata, and by the appearance of a thick stem dendrite originating from one pole of the soma. To improve slice viability, we performed all measurements at $29-31^{\circ} \mathrm{C}$.

Electrophysiological recordings and data analysis. During recording and biocytin filling the membrane properties and firing characteristics of CR cells were determined in the fast current-clamp configuration. Potentials were amplified with an EPC9-2 (HEKA Electronics, Lambrecht, Germany). Recordings were filtered at $2-5 \mathrm{kHz}$, digitized at $5-10 \mathrm{kHz}$ with an ITC-16 interface (Instrutech, Great Neck, NY), and stored on a hard disk of a Macintosh computer. Extracellular stimulation in layers 1 and $2 / 3$ was performed with patch pipettes filled with $1 \mathrm{M} \mathrm{NaCl}$. The stimulus intensity was adjusted to $5-50 \mathrm{~V}$. The stimulus frequency never exceeded $0.033 \mathrm{~Hz}$.

Decay time constants were determined from single-exponential fits to the decay phase of the NMDA EPSCs and from double-exponential fits to the decay phase of the GABA PSCs of averaged synaptic responses, respectively. All mean values are given with the SD.

Histological procedures. After recording and intracellular filling with biocytin, the brain slices were fixed in $100 \mathrm{~mm}$ PBS, pH 7.4, containing $1 \%$ paraformaldehyde and $2.5 \%$ glutaraldehyde at $4^{\circ} \mathrm{C}$ for at least $24 \mathrm{hr}$. They then were processed for light and/or electron microscopy as described previously (Lübke et al., 2000). In brief, after incubation in ABC Elite solution (Camon, Wiesbaden, Germany) overnight, the slices were preincubated in 3'3-diaminobenzidine (Sigma-Aldrich) and visualized by adding $0.025 \% \mathrm{H}_{2} \mathrm{O}_{2}$ to the solution. The reaction was stopped when dendritic and axonal processes were clearly visible. After several washing steps in $100 \mathrm{~mm}$ PBS, the sections after brief postfixation in osmium tetroxide (1-2 min) were embedded in Moviol (Hoechst AG, Frankfurt AM, Germany; light microscopy) or after longer osmification $(0.5 \%$ $\mathrm{OsO}_{4}$ in $100 \mathrm{~mm}$ PBS; $30 \mathrm{~min}$ ) and dehydration in ethanol were processed for conventional electron microscopy. Ultrathin sections were cut with an ultramicrotome (Leitz Ultracut, Hamburg, Germany), counterstained, and examined with a Philips CM 100 electron microscope (Philips, Eindhoven, The Netherlands).

Morphological reconstructions of biocytin-filled neurons. Only neurons for which a complete physiological analysis was made and that had no obvious truncation of their dendritic and axonal profiles were used for qualitative and quantitative analysis of their morphology. Neurons were photographed at various magnifications to document their dendritic morphology and axonal projection. Representative examples were drawn with the aid of a camera lucida attached to an Olympus BX50 microscope (Olympus, Hamburg, Germany) at a final magnification of $720 \times(60 \times$ objective and $12 \times$ eyepiece). These reconstructions provided the basis for further quantitative morphological analysis of the following parameters: (1) mean length of the stem dendrites, (2) total length of the axon, (3) total number and density of synaptic boutons, and (4) maximal horizontal field span of axonal collaterals. Measurements were not corrected for shrinkage. For all data the means \pm SD were calculated.

GABA-postembedding immunogold labeling. The immunogold staining procedure was performed as described by Somogyi and Hodgson (1985), using a commercially available antiserum against GABA (Sigma, München, Germany). The immunostaining was performed on droplets of Millipore-filtered solutions in humid Petri dishes. Immersion in $1 \%$ periodate $(10 \mathrm{~min})$ was followed by several washes in double-distilled water. Thereafter, the grids were transferred via 2 or $5 \%$ sodium metaperiodate $(10-30 \mathrm{~min})$ and rinsed several times in double-distilled water and three times in Tris-buffered saline (TBS), pH 7.4. After preincubation in $1 \%$ ovalbumin dissolved in TBS $(30 \mathrm{~min})$, the grids were incubated in rabbit anti-GABA antiserum (1:5000 in 1\% normal goat serum in TBS). After being rinsed in TBS and $50 \mathrm{~mm}$ Tris buffer, $\mathrm{pH} 7.4$, containing $1 \%$ bovine serum and $0.5 \%$ Tween $20(10 \mathrm{~min})$, the grids were incubated in the secondary antibody (goat anti-rabbit IgG-coated colloidal gold; $10 \mathrm{~nm}$ ) for $2 \mathrm{hr}$ (diluted 1:10, in darkness). After being rinsed in $2 \%$ glutaraldehyde $(10 \mathrm{~min})$, the grids were washed again in doubledistilled water and stained with uranyl acetate and lead citrate. In control experiments without the primary antibody and sections processed for GABA after immunogold labeling, almost no or only low background labeling was detected, whereas the labeling of GABAergic structures clearly exceeded the mean gold particle density of the maximum background staining (by at least $4 \mathrm{SD}$ ).

\section{RESULTS \\ Morphology of CR cells}

CR cells can be found throughout the entire layer 1; however, the majority was located directly underneath the pial surface. They were identified under IR-GC optics by the size and shape of their somata, a prominent and mainly horizontally oriented stem dendrite originating from one pole of the soma, and by their characteristic action potential firing pattern (Hestrin and Armstrong, 1996; Zhou and Hablitz, 1996a,b; Kilb and Luhmann, 2000; this study).

\section{Typical CR cells}

Typical CR cells represented the majority ( $n=126 ; 75 \%$ of the total population) of these neurons in layer 1 (Figs. 1, 2, 12B). Typical CR cells had ovoid or elongated somata with a horizontal diameter of $25.7 \pm 5.3 \mu \mathrm{m}$ (see also Table 1 ) and were characterized by a prominent horizontally oriented thick stem dendrite originating from one pole of the soma (Figs. $1 A 1-A 3,2)$. Along its course this dendrite gave rise to short $(20-50 \mu \mathrm{m})$ secondary and tertiary dendrites that were oriented mainly vertically toward the pial surface (Fig. 1A1-A3). The majority of CR dendrites was covered with spine-like protrusions (Fig. 1A1,A3); however, some neurons had smooth dendrites without any appendages and short dendrites (Fig. 1A2). Occasionally, CR cells also formed a terminal tuft at the most distal portion of the stem dendrite (Fig. 1A3). Some of the stem dendrites could be followed over wide distances, with a mean dendritic length of $181.9 \pm 54.1 \mu \mathrm{m}$ (minimum, $92.1 \mu \mathrm{m}$; maximum, $315.8 \mu \mathrm{m}$; see also Table 1). Some of the dendrites terminated in growth cones that could be found even on CR cells injected in P10 rats, suggesting that these neurons were still in the process of maturation (data not shown).

The main axon originates always from the opposite pole of the soma and never from the stem dendrite. The majority of CR cells that were investigated $(\sim 70 \%)$ possessed an axon that projected over a wide range of cortical surface, with individual long-range horizontal collaterals that were $>1 \mathrm{~mm}$ in length at this age (Figs. $1 B 1, B 2,2$; see also Table 2). These long-range horizontal collaterals were seen to run parallel to the pial surface, with a maximum field span of $1710.0 \pm 238.6 \mu \mathrm{m}$ (minimum, $1013.2 \mu \mathrm{m}$; maximum, $2243.6 \mu \mathrm{m} ; n=20)$. On its course the main axon gave 

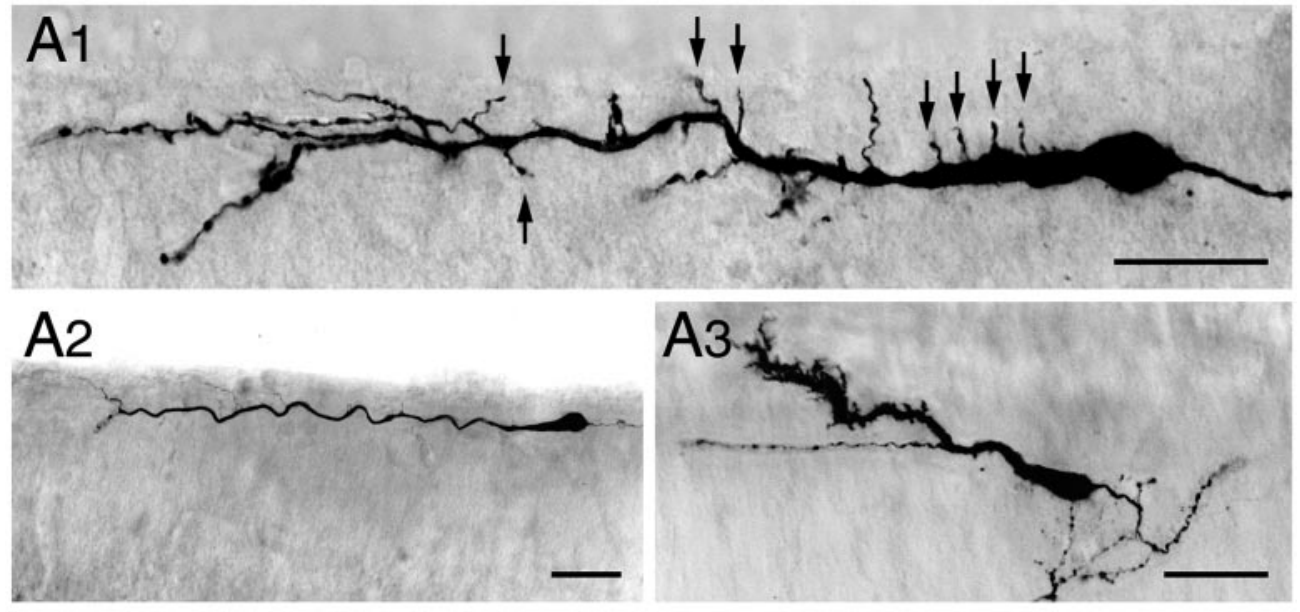

Figure 1. Dendritic and axonal morphology of typical CR cells. A1-A3, Light microscopic images of biocytinfilled CR cells showing the heterogeneity in their dendritic morphology with respect to the length of the stem dendrite, side branches, and frequency of spine-like appendages. The CR cell in $A 1$ has a relatively high number of side branches and spine-like appendages (indicated by arrows); the CR cell in $A 2$ has a single smooth stem dendrite; the CR cell in $A 3$ is an example with a shortstem dendrite terminating in a terminal tuft-like structure with short spine-like appendages. Scale bars: $A 1,20 \mu \mathrm{m} ; A 2$, $A 3,25 \mu \mathrm{m}$. B1, B2, Axonal projections of typical CR cells. The main axon emerges directly from the soma, running parallel to the pial surface with short collaterals that form periodically spaced cluster-like structures. The entire axonal arborization is confined to layer 1. The framed area in B2 is shown at higher magnification in B3. Scale bars: $B 1, B 2,50 \mu \mathrm{m}$. $B 3$, High magnification of a cluster-like axonal arborization with an axonal growth cone (asterisk). Scale bar, $10 \mu \mathrm{m}$. B4, Axonal growth cone of a CR cell axon in layer 1. Note the typical filopodia. Scale bar, 5 $\mu \mathrm{m}$. All figures are oriented such that the pial surface is on top.
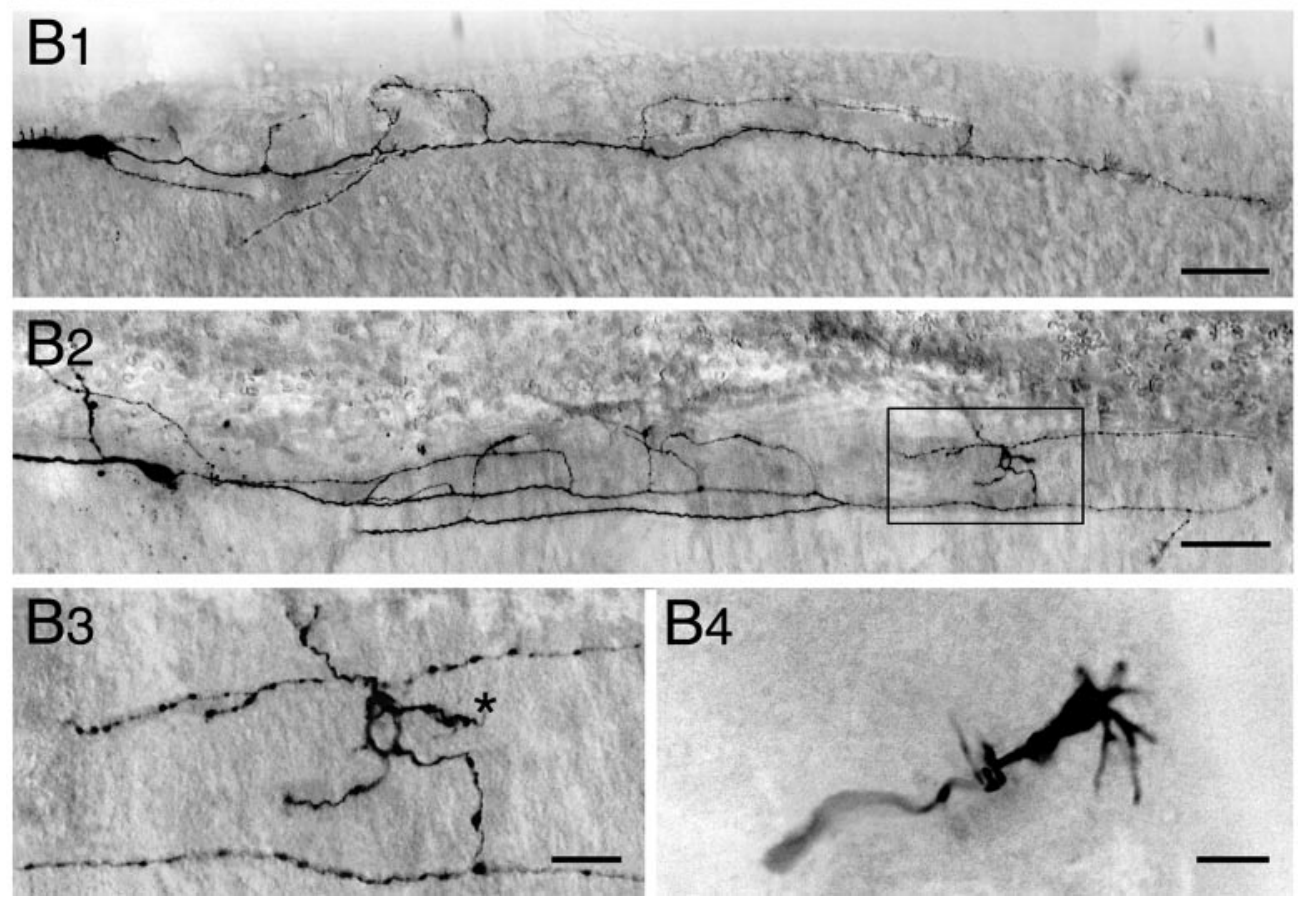

rise to several mainly vertically oriented side branches that, near the soma, formed cluster-like domains in layer 1 (Figs. 1B1,B2, $2 A-C)$. For typical $\mathrm{CR}$ cells the axons were confined entirely to layer 1 (Figs. $1 B 1, B 2,2,12 B$ ). Occasionally, axonal growth cones could be observed (Fig. 1B2-B4), indicating that some of these axons were still in the process of elongation.

Another striking feature of CR cells was the high density of synaptic boutons found at this age (see Table 2). For comparison, the number of synaptic boutons counted per $100 \mu \mathrm{m}$ axonal segment of spiny stellate and pyramidal neurons was not significantly higher, but these data were from older animals (15-25 d; Lübke et al., 2000). The finding that CR cells possess an extensive axonal projection already at an early postnatal stage raised the question of its functional relevance. The long-range horizontal projection of the axon, together with a comparably high density of synaptic boutons, may indicate the existence of a rather extensive neuronal network in layer 1 . One may speculate that CR cells could integrate cortical signal flow originating from neurons in the underlying cortical layers over a wide area of cortical surface already in an immature cortex (P5-P15).

\section{Atypical CR cells}

A subpopulation of CR cells differed from typical CR cells in their dendritic configuration (Fig. 3) and/or the projections of their axons (Figs. 4, 12B) and therefore was classified as "atypical" CR cells. They were fewer in number, and their location in layer 1 was different from those of typical CR cells.

The somata of atypical CR cells (horizontal diameter, $25.9 \pm$ $8.7 \mu \mathrm{m}$; see Table 1) were located right underneath the pial surface, in the middle half of layer 1 , or near the border between layers 1 and 2/3 (Fig. 4). From the soma of atypical CR cells either two or more thick stem dendrites of similar size originated directly from the soma (Fig. $3 A$ ). More frequently, the stem dendrites gave rise to twinned dendrites (Fig. $3 B$ ) or had shorter secondary and higher order dendrites that branched off and then took a vertical and/or horizontal course (Fig. $3 C$ ). Some of these dendrites were seen to terminate in layer $2 / 3$. In a few cases even somata and proximal dendrites were oriented vertically (Fig. 3D). As shown for typical CR cells, the majority of dendrites was covered with spine-like protrusions. Some neurons formed small 
A
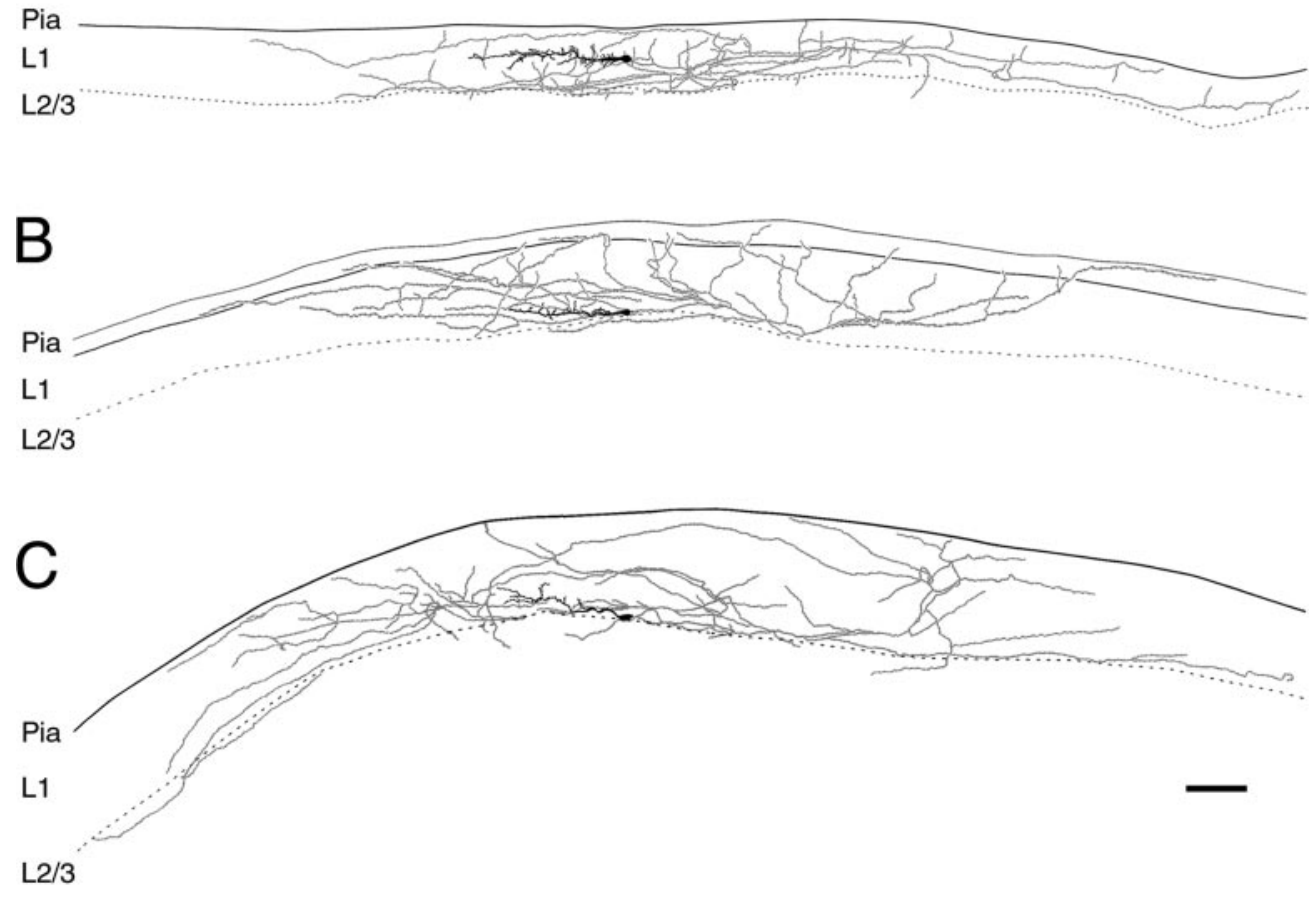

Figure 2. Camera lucida reconstructions of typical CR cells. $A-C$, Three representative examples of $\mathrm{CR}$ cells with a typical axonal projection that is confined to layer 1 (L1). The somata and dendrites are drawn in black and the axonal arborization in gray. Top lines indicate the pial surface; dashed lines indicate the border between layer 1 and layer $2 / 3$. In $B$, the middle line represents the pial surface-ependymal transition zone. All CR cells have longrange horizontal axons that project up to $2 \mathrm{~mm}$ of cortical surface. Scale bar, $100 \mu \mathrm{m}$.

terminal tufts at their tips (Fig. 3A, inset), whereas others had smooth dendrites without any appendages.

For most CR cells with an atypical dendritic configuration the axonal projection and density of synaptic boutons were similar to those of typical CR cells with a maximal field span of $1.5-2 \mathrm{~mm}$. However, CR cells were found that, besides their projection within layer 1 , had descending axonal collaterals that were seen to terminate in layer $2 / 3$ (Figs. 4, 12B). Furthermore, the axonal plexus of such neurons was less dense than that of typical CR cells (compare Figs. 4, $12 C$ with 2, 12B).

\section{Electrophysiological characteristics}

Membrane properties and firing pattern were not different in typical and atypical CR cells and corresponded well to the electrophysiological characteristics described previously for CR cells in younger animals (Kim et al., 1995; Hestrin and Armstrong, 1996; Zhou and Hablitz, 1996a; Kilb and Luhmann, 2000). CR cells had a relatively depolarized average resting membrane potential of $-44.6 \pm 7 \mathrm{mV}$ and a high input resistance of $1.2 \pm 0.8$ $\mathrm{G} \Omega$. However, no change in resting membrane potential with age was observed within the time window that was investigated (P5P11), as described by Zhou and Hablitz (1996a). Regular action potential firing could be initiated by depolarizing current injection in the majority of CR cells (Fig. 5A1,A2). Some cells fired only a few initial action potentials at depolarization; in some cases the sequences of action potentials were separated by silent intervals with no firing (data not shown). A sequence of action potentials was characterized by a pronounced spike broadening (Fig. $5 A 1, A 2)$. A sag, indicating the existence of an $I_{\mathrm{h}}$ current, was activated by hyperpolarizing current pulses (Fig. 5A1,A2). At $29-31^{\circ} \mathrm{C}$ and a membrane potential of $-60 \mathrm{mV}$ the action potentials had a long half-width of $6.4 \pm 2.3 \mathrm{msec}(n=22)$. There was no significant difference in the half-width of action potentials elicited from hyperpolarized membrane potentials ( -90 and -80 $\mathrm{mV}$ ) to remove $\mathrm{Na}^{+}$channel inactivation (data not shown). In contrast, layer 1 interneurons at the same age were fast-spiking, with short-duration action potentials (half-width, $1.9 \pm 1.3 \mathrm{msec}$ ) and pronounced afterhyperpolarizations (Fig. 5B, $C$; cf. Hestrin and Armstrong, 1996).

\section{Input synapses to $C R$ cells}

The existence of synaptic input to CR cells is still discussed controversially. Somatic and dendritic input synapses have been found on embryonic CR cells (König and Marty, 1981), but only a few postnatal cells appear to bear synapses (König and Marty, 1981; Derer and Derer, 1990, 1992). Furthermore, morphological data on the neurotransmitter phenotype of these inputs are presently not available; however, electrophysiological and imaging studies in rat and mouse suggest that $C R$ cells may receive glutamatergic, GABAergic, serotonergic, and noradrenergic inputs (Kim et al., 1995; Schwartz et al., 1998; Aguiló et al., 1999; Kilb et al., 2001). We therefore looked for synaptic inputs on morphologically and physiologically identified CR cells, using a combination of intracellular biocytin labeling and GABApostembedding immunohistochemistry ( $n=5$ CR cells). In contrast to previous studies, CR cells receive dense synaptic input (Fig. 6A). Synaptic boutons terminating onto CR cells were found on somata (Fig. $6 A-C$ ), proximal (Fig. $6 D, E$ ) and distal dendrites (Fig. $6 F, G$ ) directly on dendritic shafts (Fig. $6 E-G$ ), or on spinelike appendages (Fig. 6D). CR cells received input from both GABAergic and non-GABAergic synapses. Dense GABAergic input was found particularly at the somatic region (Fig. 6B,C) and proximal parts of the stem dendrite. Non-GABAergic inputs were found both on the proximal and distal dendrites of CR cells (Fig. 6D,F).

\section{Postsynaptic target structures of CR cells}

It is not known whether cortical CR cells establish functional output synapses. However, as shown in Table 2, CR cells have a relatively high density of synaptic boutons for this developmental 


\begin{tabular}{lcc}
\hline $\begin{array}{l}\text { Table 1. Quantitative parameters of somata and dendrites of Cajal- } \\
\text { Retzius cells }\end{array}$ & $\begin{array}{l}\text { Typical Cajal- } \\
\text { Retzius cells } \\
(n=28)\end{array}$ & $\begin{array}{l}\text { Atypical Cajal- } \\
\text { Retzius cells } \\
(n=24)\end{array}$ \\
\hline Vertical soma diameter $(\mu \mathrm{m})$ & $10.1 \pm 1.8$ & $10.9 \pm 2.8$ \\
Minimum & 7.1 & 5.1 \\
Maximum & 14.1 & 16.6 \\
Horizontal soma diameter $(\mu \mathrm{m})$ & $25.7 \pm 5.3$ & $25.9 \pm 8.7$ \\
Minimum & 15.4 & 12.8 \\
Maximum & 34.6 & 52.6 \\
Length of stem dendrite $(\mu \mathrm{m})$ & $181.9 \pm 54.1$ & $188.8 \pm 81.2^{*}$ \\
& & $176.3 \pm 60.7^{*}$ \\
Number of side branches & $5.5 \pm 3.2$ & $149.2 \pm 73.6^{*}$ \\
Minimum & 0 & $5.2 \pm 3.3$ \\
Maximum & 16 & 0 \\
Occurrence of dendritic spines & $70 \%$ & $75 \%$
\end{tabular}

*Indicates primary, secondary, and tertiary stem dendrites of atypical Cajal-Retzius cells. These dendrites either emerge directly from the soma or very proximal $<25$ $\mu \mathrm{m}$ from the stem dendrite. All values are given as mean $\pm \mathrm{SD}$.

stage when compared with bouton counts of principal neurons taken from older rats (Lübke et al., 2000). We therefore examined whether CR cells establish synaptic contacts and what their postsynaptic target structures are. Synaptic contacts between the axonal collaterals of biocytin-labeled CR cells and postsynaptic target structures could be identified in serial ultrathin sections through the entire axonal domain of CR cells $(n=4)$. Axonal collaterals and synaptic boutons could be identified easily by the presence of the dark diaminobenzidine-reaction product. Asym- metric synaptic contacts with the following features were observed: the presence of synaptic vesicles in the bouton, a clear synaptic cleft, and a postsynaptic dense region (Fig. 7).

To identify further the transmitter phenotype of the postsynaptic target structures, we performed GABA-postembedding immunogold labeling. Synaptic boutons were found on dendritic shafts (Fig. 7A,C,D) and spine-like appendages (Fig. 7B). The majority was established on dendritic shafts that were variable in size. All biocytin-labeled boutons that were investigated $(n=53)$ formed en passant synapses on non-GABAergic dendritic profiles, suggesting that CR cells specifically innervate non-GABAergic, presumably glutamatergic, structures. Postsynaptic targets could be terminal tuft dendrites of pyramidal neurons, although in layer 1 GABAergic synapses, dendrites and somata (indicated by gold grains) were observed frequently at this age (data not shown). We cannot rule out the possibility that CR cell axons also may establish synaptic contacts with GABAergic neurons. However, our findings suggest that the target neurons of CR cells are predominantly non-GABAergic, presumably glutamatergic, neurons.

\section{Synaptic physiology of CR cells}

To verify that the morphologically identified input synapses are functional, we performed extracellular stimulation experiments to activate postsynaptic responses in CR cells, which then were characterized pharmacologically. In all experiments the postsynaptic CR cell was filled with biocytin via the recording pipettes to allow for a morphological cell identification. No spontaneous synaptic activity was present in CR cells in the time window that was investigated (P5-P11).

Figure 8 shows synaptic responses evoked by extracellular stimulation in layer 1 in a morphologically identified CR cell. In control saline (Fig. 8B1) a large postsynaptic potential was elic-

Table 2. Quantitative parameters of the axon of Cajal-Retzius cells in layer 1

\begin{tabular}{|c|c|c|c|c|}
\hline Reference number & $\begin{array}{l}\text { Total length of ax- } \\
\text { onal collaterals }(\mu \mathrm{m})\end{array}$ & $\begin{array}{l}\text { Maximal field span of } \\
\text { axonal collaterals }(\mu \mathrm{m})\end{array}$ & $\begin{array}{l}\text { Total number of } \\
\text { synaptic boutons }\end{array}$ & $\begin{array}{l}\text { Number of boutons } / 100 \\
\mu \mathrm{m} \text { axonal segment }\end{array}$ \\
\hline CR230500C & 7094.9 & 1832.1 & 713 & 10.0 \\
\hline CR050600A & 7384.6 & 1817.9 & 837 & 11.3 \\
\hline CR050600B & 6571.3 & 1870.5 & 937 & 14.3 \\
\hline CR110700C & 9325.8 & 1839.8 & 974 & 10.5 \\
\hline CR190700C & 9637.5 & 1783.3 & 1179 & 12.2 \\
\hline CR191000D & 8081.3 & 1711.5 & 971 & 12.1 \\
\hline CR191200C & 5211.9 & 1611.8 & 639 & 12.3 \\
\hline CR191200D & 6219.7 & 1498.6 & 709 & 11.4 \\
\hline CR100101A & 6144.7 & 1666.7 & 717 & 11.7 \\
\hline CR100101B & 5513.2 & 1013.2 & 648 & 11.8 \\
\hline CR290301D & 6973.7 & 2243.6 & 1180 & 16.9 \\
\hline CR050401A & 6987.7 & 1537.8 & 747 & 10.7 \\
\hline CR100401A & 6033.7 & 1799.7 & 787 & 15.0 \\
\hline CR300401A & 7324.5 & 1877.9 & 1021 & 13.9 \\
\hline CR030501D & 6856.4 & 1598.9 & 803 & 11.7 \\
\hline CR170501B & 5539.5 & 1469.2 & 785 & 14.2 \\
\hline CR220501C & 7197.4 & 1948.7 & 726 & 10.0 \\
\hline CR110601A & 8221.6 & 1876.3 & 836 & 10.2 \\
\hline CR110601B & 7023.1 & 1655.3 & 757 & 10.8 \\
\hline CR150601D & 6367.9 & 1609.7 & 678 & 10.6 \\
\hline Mean & 6930.0 & 1710.0 & 825.3 & 12.0 \\
\hline $\mathrm{SD}$ & 1162.6 & 238.6 & 160.4 & 1.7 \\
\hline Median & 6973.7 & 1711.5 & 785.0 & 11.7 \\
\hline
\end{tabular}

To demonstrate variability of morphological parameters between different CR cells, data from individual neurons are listed. 

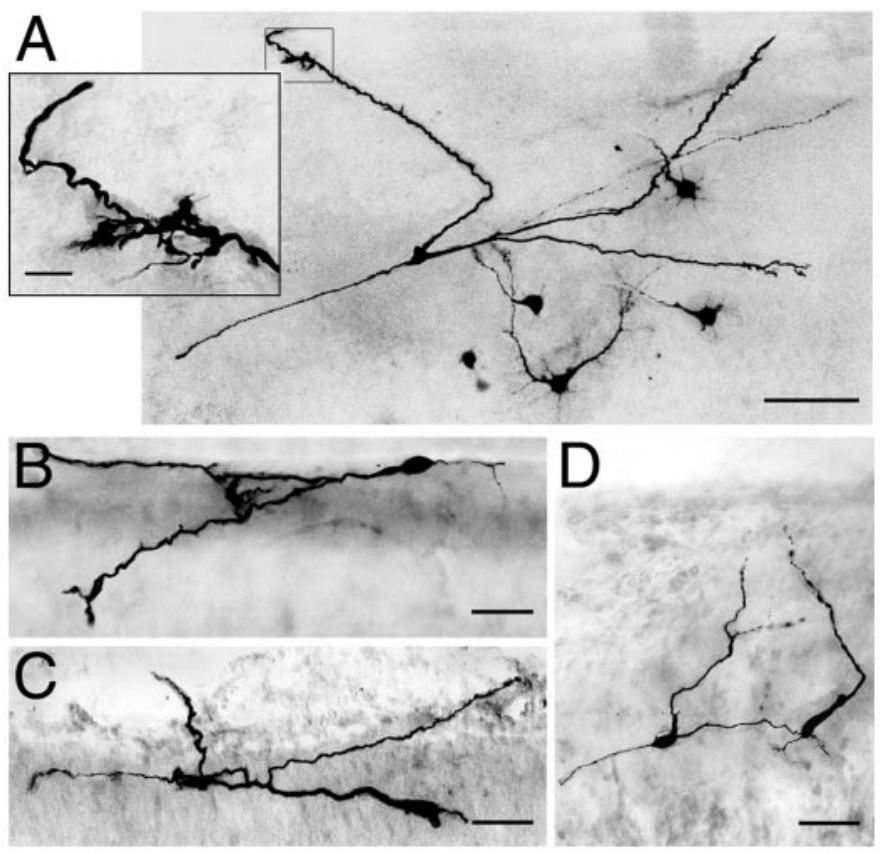

Figure 3. Dendritic morphology of atypical CR cells. $A-D$, Light microscopic images of biocytin-filled CR cells with an atypical dendritic configuration. Atypical CR cells are characterized by two prominent dendrites of similar caliber and length emerging directly from the soma $(A)$, by twinned dendrites of similar size and length $(B)$, vertically and horizontally oriented dendrites of different order and size $(C)$, and stem dendrites that are oriented vertically toward the pial surface $(D)$. Some of these dendrites form terminal tufts at their tips (inset in $A$ ). Intracellular injection of biocytin in an individual CR cell often results in additional staining of a cluster of 4-10 neurons in the underlying cortical layers. All figures are oriented such that the pial surface is on top. Scale bars: $A, 100$ $\mu \mathrm{m}$; inset in $A, 10 \mu \mathrm{m} ; B-D, 25 \mu \mathrm{m}$.

ited that either was blocked $(n=3)$ or was reduced significantly $(n=11)$ by the $\mathrm{GABA}_{\mathrm{A}}$ receptor antagonist bicuculline $(20 \mu \mathrm{M})$ (Fig. 8B2). The subsequent application of the non-NMDA receptor antagonist NBQX $(10 \mu \mathrm{M})$ (Fig. 8B3) was without effect $(n=$ $6)$, whereas the NMDA receptor antagonist D-AP-5 (50 $\mu \mathrm{M})$ (Fig.
$8 B 4$ ) caused a complete inhibition of the synaptic response $(n=$ $6)$. Reversing the order of the glutamate receptor antagonists (i.e., application of D-AP-5 before NBQX) resulted in a complete block of the synaptic response directly after the D-AP-5 application, indicating that glutamatergic synaptic responses in CR cells are mediated exclusively by NMDA receptors.

\section{GABAergic synaptic responses}

To characterize the synaptic response, we evoked $\mathrm{GABA}_{\mathrm{A}}$ receptor-mediated PSPs and PSCs in the presence of glutamate receptor antagonists (10 $\mu \mathrm{M}$ NBQX and $50 \mu \mathrm{M}$ D-AP-5 or $25 \mu \mathrm{M}$ 7 -chlorokynurenate). Very low stimulation frequencies $(0.025$ $0.016 \mathrm{~Hz}$ ) had to be used to prevent a rapid rundown of the synaptic response. Under these conditions $\mathrm{GABA}_{\mathrm{A}}$ receptormediated PSPs showed little fluctuation, and their amplitude was

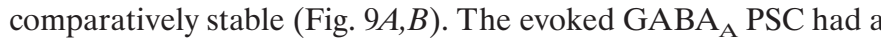
slow time course and decayed in a double-exponential manner $\left(\tau_{1}=13.2 \pm 7.6 \mathrm{msec} ; \tau_{2}=134.1 \pm 84.9 \mathrm{msec} ; n=9\right)($ Fig. $9 C, D)$. In all of the cases that were tested, bicuculline blocked the $\mathrm{GABA}_{\mathrm{A}}$ PSC entirely $(n=11)$ (Fig. $\left.9 C\right)$.

\section{Glutamatergic synaptic responses}

When GABAergic synaptic activity was blocked with bicuculline, small EPSPs $(0.5-1 \mathrm{mV})$ could be evoked even in the presence of $1 \mathrm{mM} \mathrm{Mg}^{2+}$ (at $-60 \mathrm{mV}$ ) (Fig. 8B3). When $\mathrm{Mg}^{2+}$ was removed from the bath solution, extracellular stimulation resulted in a synaptic current that was mediated entirely by NMDA receptors and inhibited completely by $50 \mu \mathrm{M}$ D-AP-5 (Fig. 10 $\mathrm{A}$ ). In the time window that was investigated (P5-P11), no AMPA receptormediated synaptic current could be evoked. In $0 \mathrm{Mg}^{2+}$ and at $\sim 30^{\circ} \mathrm{C}$ the NMDA EPSC decayed exponentially with a time constant of $118.9 \pm 16.9 \mathrm{msec}(n=9)$ (Fig. 10B). For diheteromeric recombinant NMDA receptors composed of the NR1 and the NR2B subunit, a decay time constant of $300 \mathrm{msec}$ was measured at room temperature (Monyer et al., 1994). Given a temperature difference of $\sim 8^{\circ} \mathrm{C}$ between room temperature and our recording temperature and a $\mathrm{Q}_{10}$ of $2-3$, the decay time constants are in good agreement. In addition, at a concentration of $1 \mu \mathrm{M}$ the noncompetitive NMDA receptor antagonist ifenprodil (Williams,

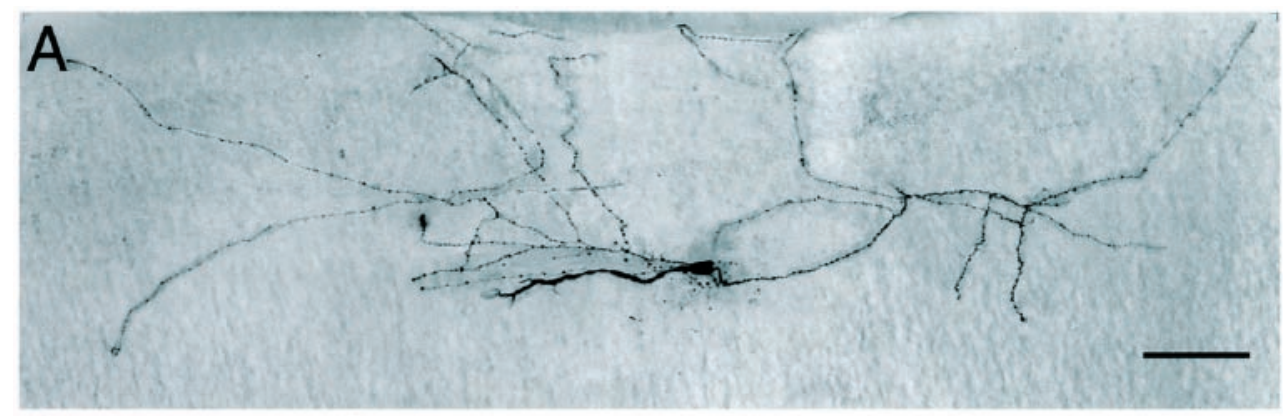

Figure 4. CR cell with an atypical axonal projection. $A$, Low-power light microscopic image of a CR cell with an axonal projection that is not confined to layer 1 . The soma and dendrites of the neuron are located at the border between layer 1 and layer $2 / 3$. In this case the axonal arborization in layer 1 is not as dense as for typical CR cells and has numerous vertically oriented collaterals. Scale bar, $100 \mu \mathrm{m}$. $B$, Corresponding camera lucida reconstruction of the neuron shown in $A$. The soma and dendrites are drawn in black and the axonal arborization is drawn in red. Top black line indicates the ependymal surface; the dashed line indicates the border between layer 1 and layer $2 / 3$. Bottom black line represents the pial surface-ependymal transition zone. A large fraction of the axonal collaterals in layer 1 is vertically oriented, terminating in the ependymal zone. Several axonal collaterals are located clearly in layer $2 / 3$. Scale bar, $100 \mu \mathrm{m}$. 


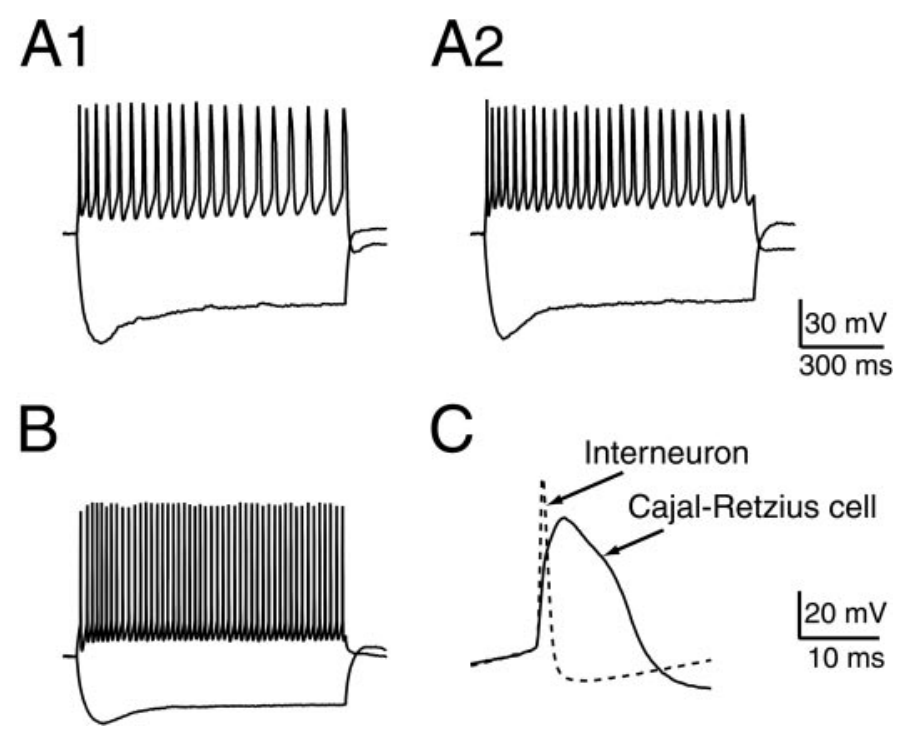

Figure 5. Electrophysiological characteristics of typical and atypical CR cells compared with GABAergic interneurons in layer 1. $A$, Voltage responses of a typical $(A 1)$ and an atypical CR cell $(A 2)$ to depolarizing and hyperpolarizing current pulses of $1 \mathrm{sec}$ duration; the membrane potential of both cells was held close to $-60 \mathrm{mV}$. There were no significant differences in the firing patterns of CR cells with typical and atypical morphologies. Both types of CR cells fired long-duration action potentials (pooled data: half-width, $6.4 \pm 2.4 \mathrm{msec}$ ). A train of action potentials was characterized by adaptation and spike broadening. Both CR cells show a characteristic sag in the hyperpolarizing response indicative of the presence of $I_{\mathrm{h}} . B$, Recordings showing the voltage responses of a GABAergic interneuron in layer 1 to depolarizing and hyperpolarizing current pulses. The GABAergic interneuron (a neurogliaform cell) fires a highfrequency train of short-duration action potentials with clear afterhyperpolarizations and no adaptation or spike broadening. A small sag was visible in the hyperpolarizing response. $C$, Comparison of action potential duration in a CR cell $(A 1$; solid line $)$ and the interneuron $(B$; dashed line). The action potentials of the two cells have been aligned to the beginning of the upstroke. The action potential firing threshold of the neurogliaform cell was $\sim 10 \mathrm{mV}$ more negative than that in the CR cell.

1993) reduced the NMDA EPSC amplitude by $38.9 \pm 8.9 \%(n=$ 7) (Fig. 10C,D). Increasing the ifenprodil concentration to $10 \mu \mathrm{M}$ suppressed the NMDA EPSC by $85.8 \pm 9.5 \%(n=4)($ Fig. $10 D)$; higher ifenprodil concentrations led to a complete inhibition of the synaptic NMDA receptor response.

At $-60 \mathrm{mV}$ and in the presence of $1 \mathrm{mM} \mathrm{Mg}^{2+}$ a clear $(0.5-2$ $\mathrm{mV}$ ) NMDA receptor-mediated EPSP could be evoked in CR cells (Fig. 11A). However, when we switched to voltage clamp, only a very small NMDA receptor current was discernible (Fig. $11 B$, gray trace). Washout of extracellular $\mathrm{Mg}^{2+}$ revealed a clear NMDA receptor-mediated EPSC that was blocked by $50 \mu \mathrm{M}$ D-AP-5. This indicates that the pure NMDA synapses onto CR cells are not "silent" synapses as have been proposed for other central neurons (Isaac et al., 1995; Liao et al., 1995) but are functional, in particular at depolarized membrane potentials.

\section{Dye coupling between CR cells and other neocortical neurons}

Dye coupling is a frequent observation in the immature neocortex (Gutnick and Prince, 1981; LoTurco and Kriegstein, 1991; Yuste et al., 1992; Peinado et al., 1993b; Rörig et al., 1996) (for review, see Peinado et al., 1993a). In $25 \%$ of the biocytin-labeled CR cells dye coupling to a group of 5-10 pyramidal neurons in layers $2 / 3$ and 5 was observed (Fig. 12B,C). Occasionally, costained nonpyramidal neurons also were found. The intensity of the staining varied with distance to the intracellularly labeled CR cells, although most pyramidal neurons were spatially very close to the $\mathrm{CR}$ cell. The staining was always very clear without any extracellular dye deposits in the surrounding tissue. At the light microscopic level some of the apical dendrites of the pyramidal neurons crossed the stem dendrites of CR cells in close apposition (Figs. $3 A, 12 A$ ), suggesting the existence of gap junctional coupling in addition to chemical synapses. Dye coupling was observed throughout the entire time window that was investigated (P5-P11).

\section{DISCUSSION}

\section{Long-range axonal projection and high density of synaptic boutons}

Together, our results suggest that CR cells are active elements in an early neuronal network. All CR cells described here were characterized by long-range horizontal axons (1000-2000 $\mu \mathrm{m})$, which is in contrast to previous studies in mouse, rat, and humans where the axonal field span never exceeded $500 \mu \mathrm{m}$ (Derer and Derer, 1990; Marín-Padilla, 1990; Hestrin and Armstrong, 1996; Aguiló et al., 1999; Kilb and Luhmann, 2001). Such widespread axons, together with the relatively high number of synaptic boutons and synaptic contacts preferentially established with nonGABAergic profiles, suggest a role for CR cells in an early cortical network. Long-range horizontal excitatory connections in the visual cortex of mature cats and monkeys that project over long distances are thought to integrate visual information of cortical columns that share the same iso-orientation (Katz et al., 1989; Bosking et al., 1997; Kisvárday et al., 1997). Taking into account that CR cells possess such long-range horizontal axons very early in development, one might speculate that CR cells integrate synaptic activity of developing pyramidal cells in the underlying cortical plate, thereby contributing to the establishment of cortical domains.

\section{Postsynaptic target structures of CR cells}

It is still unknown whether CR cells form functional output synapses, one prerequisite for an active role in a cortical network. It has been suggested previously that CR cell axons form synaptic contacts with pyramidal cell dendrites (Derer and Derer, 1990; Marín-Padilla, 1998), although direct evidence so far has been lacking. Here we demonstrate that CR cells establish en passant asymmetric synaptic contacts preferentially on dendritic shafts or spines of non-GABAergic neurons. Because the terminal tuft dendrites of neocortical pyramidal neurons are the most frequent non-GABAergic structures found in layer 1 (for review, see Marín-Padilla, 1998), these neurons are the most likely target structures of CR cells. However, the ultimate experimental proof will be paired recordings from CR cells and their postsynaptic target neurons.

\section{Synaptic inputs to CR cells}

No studies are presently available that provide detailed information about the nature, extent, or origin of synaptic inputs to $\mathrm{CR}$ cells. Ultrastructural data, so far, suggest that early postnatal CR cells receive either no synaptic input (König and Marty, 1981) or only a few synapses (Edmunds and Parnavelas, 1982; Parnavelas and Edmunds, 1983; Derer and Derer, 1990, 1992). Furthermore, the fate of synaptic inputs during development is still a matter of debate: their number either may increase (Parnavelas and Edmunds, 1983) or may decrease (Derer and Derer, 1990, 1992). In line with Edmunds and Parnavelas (1982) we found that, in P5-P11 animals, CR cells receive relatively dense synaptic input 


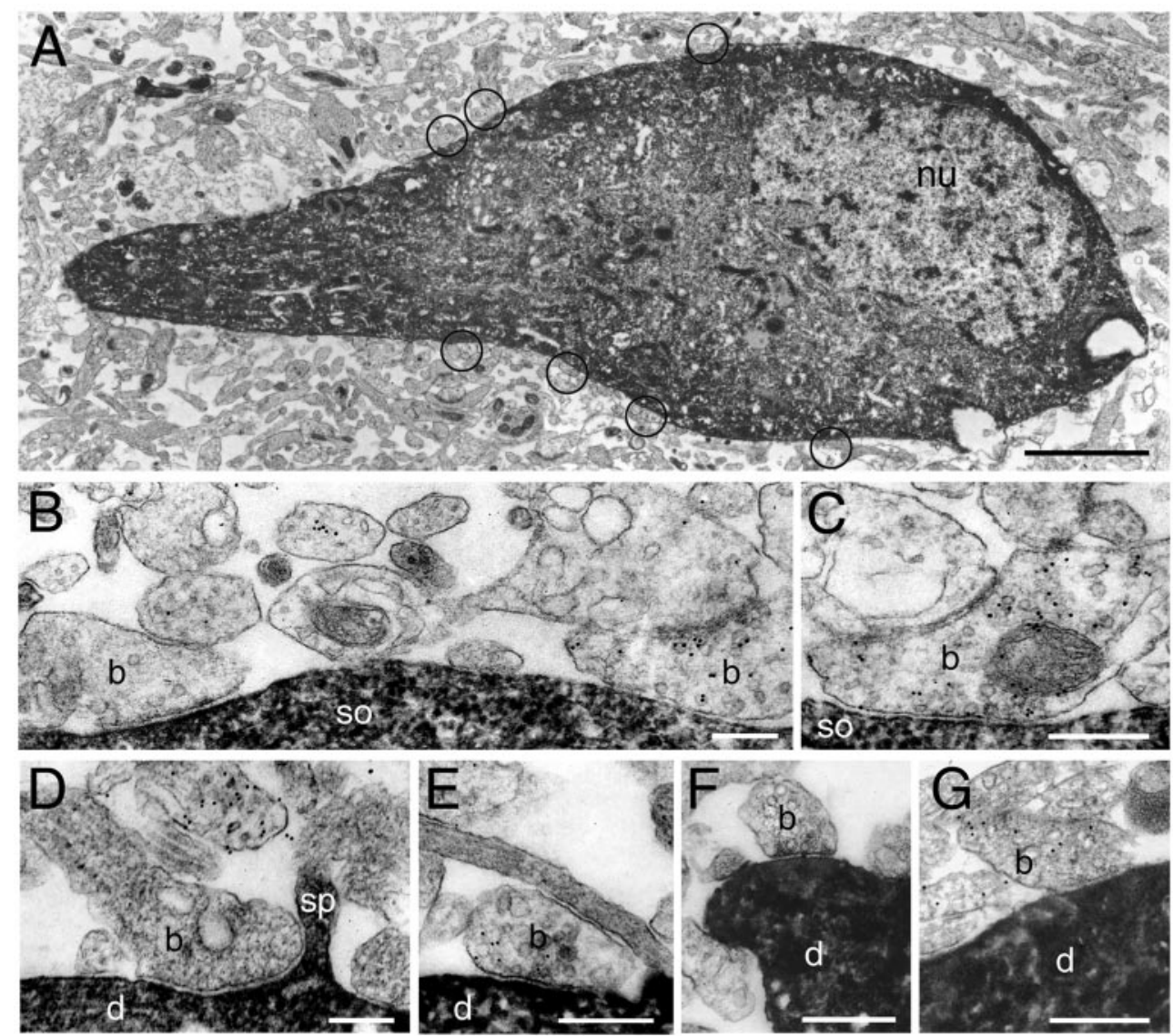

Figure 6. Synaptic input to CR cells. $A$, Low-power electron microscopic image of the somatic region with the initial segment of the stem dendrite emerging from one pole of the soma of a typical CR cell filled with biocytin (as indicated by the dark reaction product). CR cells receive relatively dense GABAergic and nonGABAergic input at the somatic region and dendrites, as shown at higher magnification in $B-G$. The nucleus ( $n u)$ of this CR cell showed an eccentric location in the cytoplasm. Circled areas mark the distribution of synaptic contacts along the soma and the initial segment of the stem dendrite. Note the large extracellular space within the neuropil that is characteristic for this age (P9). Scale bar, $2 \mu \mathrm{m}$. $B-G$, Typical examples of input synapses at the somatic region $(s o ; A-C)$ and proximal $(D, E)$ and distal dendrites $(d ; F, G)$. The synaptic contact in $D$ is established with a dendritic spine ( $s p)$. Both GABAergic (after immunogold labeling for GABA as indicated by gold grains in $B, C, G$ ) and non-GABAergic (absence of gold grains in $B, D-F)$ synapses were found. Scale bars: $B-G, 0.25 \mu \mathrm{m}$. not only on the somatic region but also on proximal as well as distal dendrites and spine-like protrusions. Both GABAergic and non-GABAergic input synapses were present at all ages that were investigated.

In agreement with the morphological findings we could evoke GABAergic and glutamatergic synaptic responses in morphologically identified CR cells of the same age range. Kilb and Luhmann

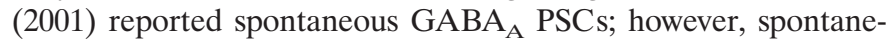
ous activity ceased after P4, consistent with our observations.

Glutamatergic inputs to morphologically identified CR cells were characterized pharmacologically as pure NMDA receptormediated EPSPs or EPSCs, respectively. No AMPA/kainate receptor-mediated responses could be elicited in all of the CR cells that were investigated. Similarly, only whole-cell NMDA responses were present in mouse CR cells, whereas AMPA receptor responses were present in human CR cells ( $\mathrm{Lu}$ et al., 2001). In addition, calcium imaging of CR cells showed a much weaker response to AMPA than to NMDA (Schwartz et al., 1998). However, in young rat CR cells (P0-P4) the occurrence of both non-NMDA and NMDA EPSCs has been reported previously (Kim et al., 1995).

NMDA receptor-mediated EPSCs had a relatively slow decay time course and were highly susceptible to block by ifenprodil, indicating that the underlying receptors were composed of the NR1 and NR2B subunits (Williams, 1993; Monyer et al., 1994). Supporting this interpretation, low ifenprodil concentrations inhibited agonist-evoked NMDA responses in CR cells (Mienville and Pesold, 1999; Lu et al., 2001). The presynaptic sites of these glutamatergic inputs may be association fibers in layer 1 or axons of pyramidal neurons in the underlying cortical layers.
Besides the inputs described here, CR cells may receive synaptic inputs via other neurotransmitters. Serotonergic inputs from the raphe nuclei or noradrenergic inputs from locus ceruleus reach the cortex early during development (Parnavelas et al., 1988) and may establish synaptic contacts with CR cells. This idea is supported further by calcium imaging (Schwartz et al., 1998), suggesting the presence of $\beta$-adrenergic receptors on CR cells. Furthermore, $\alpha_{2 \mathrm{~A}}$-adrenergic receptors have been detected in monkey CR cells (Wang and Lidow, 1997).

\section{Dye coupling between CR cells and other neurons}

In $25 \%$ of all intracellular biocytin fillings, dye coupling between CR cells and clusters of pyramidal neurons or, to a lesser extent, nonpyramidal neurons was observed at P5-P11. Because of the relatively long distance between the injected $\mathrm{CR}$ cell and the costained neurons $(>50 \mu \mathrm{m})$, somatic uptake of the dye appears rather unlikely. In support of this view, the region around the intracellularly injected CR cell was devoid of extracellular dye deposits.

Dye coupling between neocortical neurons has been proposed to be an indicator for the presence of gap junctions (Gutnick and Prince, 1981; Connors et al., 1983; LoTurco and Kriegstein; 1991; Yuste et al., 1992; Peinado et al., 1993b; Rörig et al., 1996). It occurs between pyramidal neurons but also has been observed between neurons of superficial layers (Gutnick and Prince, 1981; Kim et al., 1995). The incidence of coupling decreases dramatically during postnatal development, being almost nonexistent after the second postnatal week (Connors et al., 1983; LoTurco and Kriegstein, 1991; Kim et al., 1995; Rörig et al., 1996). This parallels the developmental decrease in the expression of the 


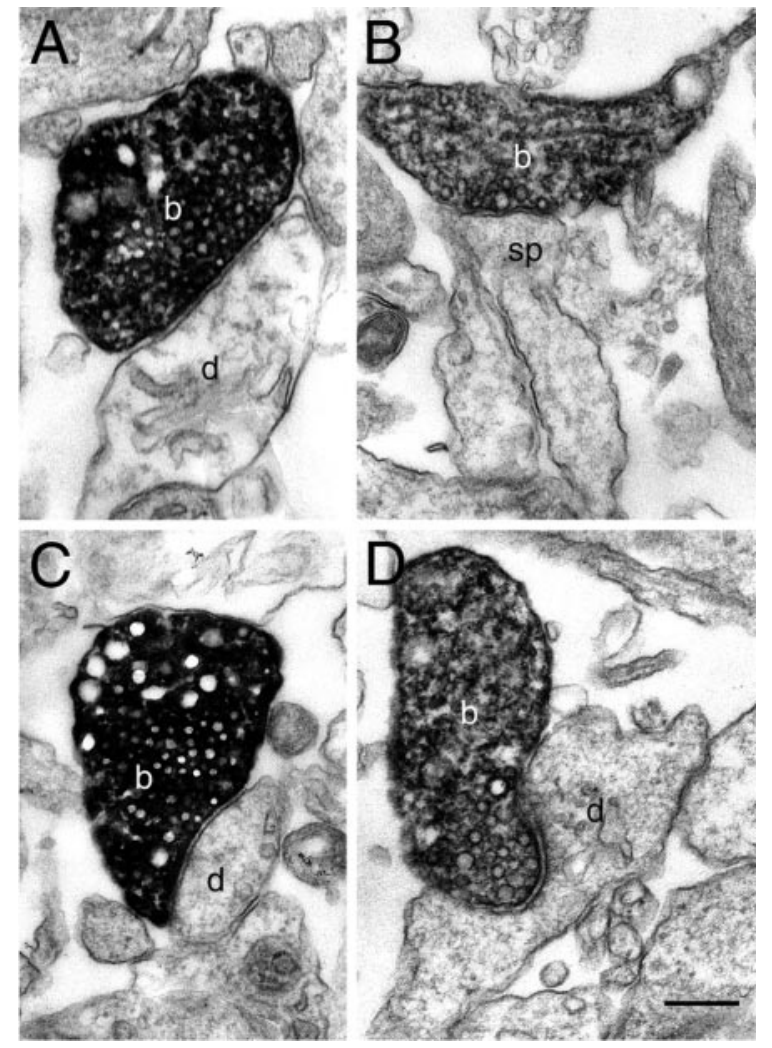

Figure 7. Postsynaptic target structures of CR cells. Shown is electron microscopy of synaptic contacts established by the axonal collaterals of CR cells on postsynaptic target structures. En passant synaptic boutons (b) are located either on dendritic shafts $(d)$ as shown in $A$, $C$, and $D$ or on the spines $(s p)$ in $B$. Note that all postsynaptic target structures are GABA-negative, as indicated by the absence of gold particles in these structures. Scale bar for $A-D, 0.25 \mu \mathrm{m}$.
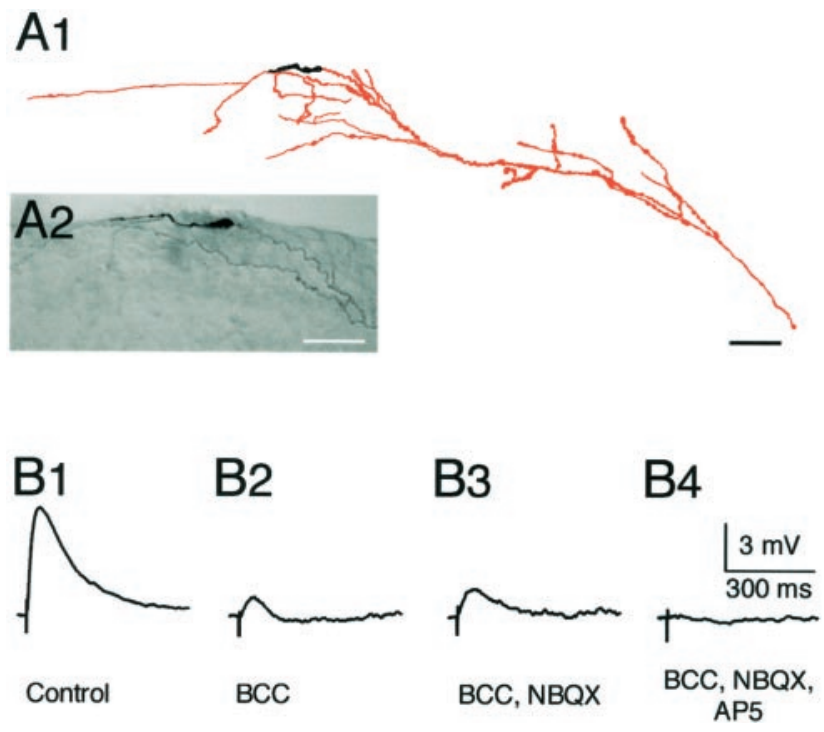

Figure 8. Synaptic responses in an identified CR cell. $A$, Reconstruction (A1; soma and dendrites, black; axon, red) and photomicrograph (A2) of a typical CR cell that was recovered after synaptic stimulation. Scale bars: $A 1,100 \mu \mathrm{m} ; A 2,50 \mu \mathrm{m}$. $B$, Synaptic responses evoked in a CR cell by stimulation in layer 1. B1, EPSP in control saline. $B 2$, After the addition of $20 \mu \mathrm{M}$ bicuculline $(B C C)$ the EPSP was strongly reduced. B3, Subsequent application of $10 \mu \mathrm{M}$ NBQX had no effect. $B 4$, Additional application of $50 \mu \mathrm{M}$ D-AP-5 abolished the response. The traces represent averages of $10-15$ EPSPs.
A
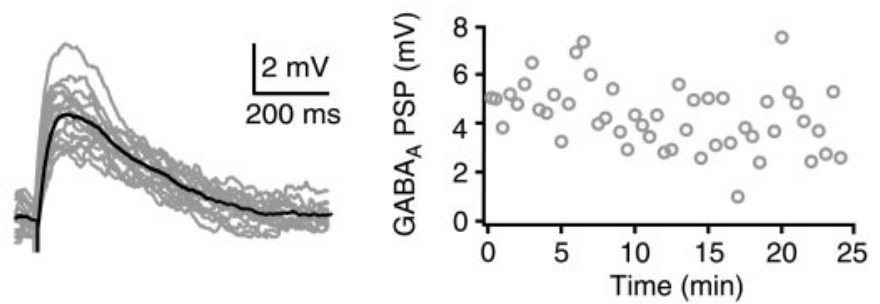

C
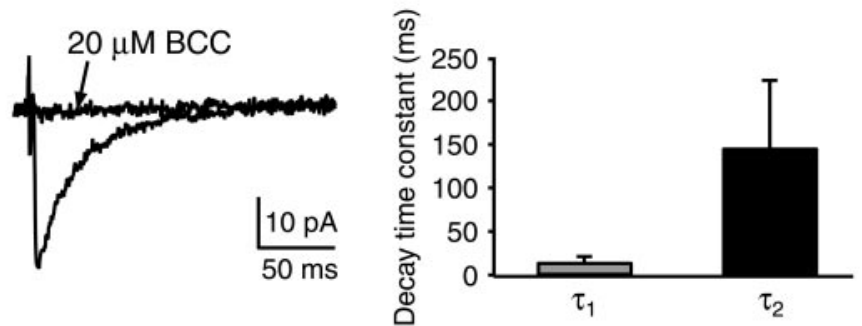

Figure 9. GABA $_{\mathrm{A}}$ receptor-mediated PSPs and PSCs. $A, \mathrm{GABA}_{\mathrm{A}}$ PSPs evoked in the presence of glutamate receptor antagonists at a holding potential of $-60 \mathrm{mV}$. Gray traces represent single responses; the black trace represents the average PSP. Note the slow decay time course of the $\mathrm{GABA}_{\mathrm{A}}$ PSPs. $B$, Peak amplitude of $\mathrm{GABA}_{\mathrm{A}}$ PSPs stimulated at a frequency of $0.05 \mathrm{~Hz}$. Higher frequency caused a rapid rundown of the signal. $C, \mathrm{GABA}_{\mathrm{A}}$ PSCs evoked in the presence of glutamate receptor antagonists. The application of $20 \mu \mathrm{M}$ bicuculline resulted in a complete block of the synaptic response. The traces represent averages of 10-15 sweeps. $D$, Evoked GABA ${ }_{\mathrm{A}}$ PSCs decayed in a double-exponential manner with a fast time constant $\left(\tau_{1}\right)$ of $13.2 \pm 7.6 \mathrm{msec}$ and a slow time constant $\left(\tau_{2}\right)$ of $134.1 \pm 84.9$ msec (significantly different, $p<0.001 ; t$ test; $n=9)$.

neuronal connexins 36 and 47 (Belluardo et al., 2000; Teubner et al., 2001). Together, it is likely that CR cells are coupled to other neurons not only via chemical synapses but also via gap junctions.

\section{Immaturity of $\mathbf{C R}$ cells}

It has been suggested that CR cells remain in "a state of persistent immaturity" (Derer and Derer, 1992) because they exhibit a number of features characteristic for immature neurons.

CR cell axons and dendrites possess growth cones (Derer and Derer, 1990; this study), and their dendrites often bear immature spine-like filopodia. They have a high input resistance and longduration action potentials suggesting a low $\mathrm{Na}^{+}$channel density (Kim et al., 1995; Hestrin and Armstrong, 1996; Zhou and Hablitz, 1996a; Kilb and Luhmann, 2000). The membrane potential is depolarized; because of a high intracellular $\mathrm{Cl}^{-}$concentration (up to $50 \mathrm{~mm}$ ), a switch to lower $\mathrm{Cl}^{-}$concentrations does not occur (Mienville, 1998). Under these conditions both GABAergic and glutamatergic synaptic inputs are depolarizing, as suggested for developing neocortical neurons (Luhmann and Prince, 1991; Agmon et al., 1996; Owens et al., 1996). Another immature feature of CR cells are glutamatergic synapses containing only NMDA receptors of the NR1/NR2B subunit composition (Monyer et al., 1994; Sheng et al., 1994; Takahashi et al., 1996; Flint et al., 1997; Stocca and Vicini, 1998; Tovar and Westbrook, 1999). Last, there appears to be a high incidence of gap junctional coupling between CR cells and other neurons, another feature of the developing neocortex.

In contrast to the persisting neurons of the neocortex, CR cells 
A

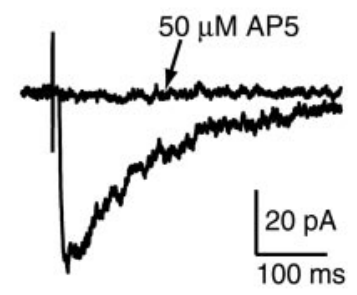

B

C
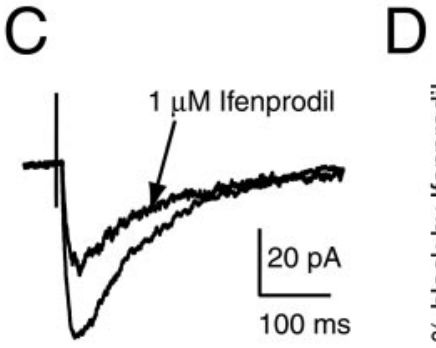

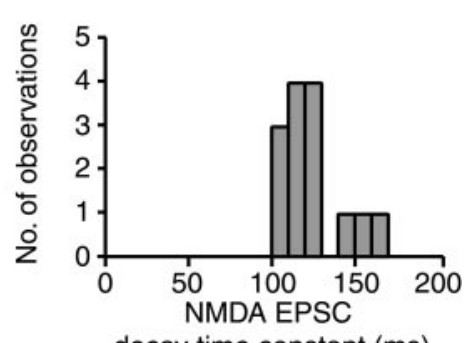

decay time constant (ms)

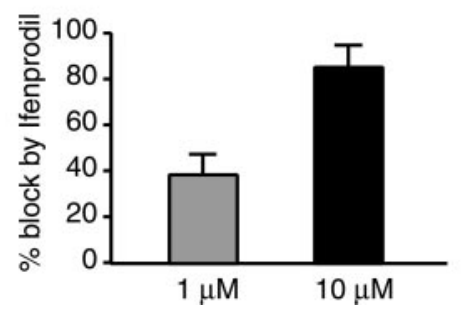

Figure 10. NMDA receptor-mediated postsynaptic currents in CR cells. $A$, Evoked NMDA receptor EPSC recorded at a holding potential of -60 $\mathrm{mV}$ in the presence of $20 \mu \mathrm{M}$ bicuculline in a $0 \mathrm{Mg}^{2+}$ solution. The EPSC was abolished completely by the addition of $50 \mu \mathrm{M}$ D-AP-5; no nonNMDA component of the EPSC was observed. The traces represent averages of 10-12 sweeps. $B$, Histogram of the NMDA EPSC decay time constants. The mean value was $118.9 \pm 16.9 \mathrm{msec}(n=6)$. $C$, Evoked NMDA EPSC in $0 \mathrm{Mg}^{2+}$ and $20 \mu \mathrm{M}$ bicuculline in the absence and presence of $1 \mu \mathrm{M}$ ifenprodil. The traces represent averages of 10-15 sweeps. $D$, Effect of 1 and $10 \mu \mathrm{M}$ ifenprodil on the peak amplitude of evoked NMDA EPSCs. The NMDA EPSC amplitude was reduced by $38.9 \pm 8.9 \%(n=7)$ and $85.8 \pm 9.5 \%(n=4)$ by 1 and $10 \mu \mathrm{M}$ ifenprodil, respectively.
A

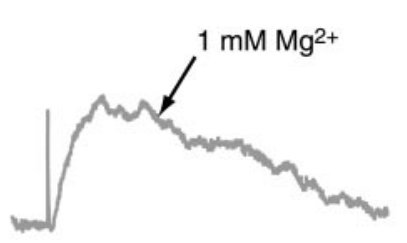

B

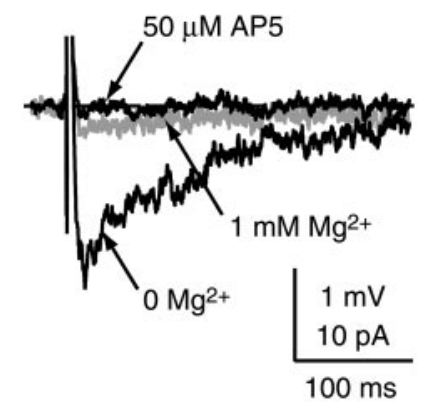

Figure 11. Pure NMDA synapses in CR cells are functional. $A$, Evoked NMDA EPSP recorded at $-60 \mathrm{mV}$ in the presence of $20 \mu \mathrm{M}$ bicuculline and $1 \mathrm{~mm}$ extracellular $\mathrm{Mg}^{2+} . B$, After switching to voltage clamp without changing the stimulus intensity and location, we could elicit only a small NMDA EPSC ( gray trace corresponds to the EPSP shown in $A$ ). Removal of extracellular $\mathrm{Mg}^{2+}$ resulted in an $\sim 10$-fold increase of the EPSC amplitude. The addition of $50 \mu \mathrm{M}$ D-AP-5 caused a complete block of the NMDA EPSC.

remain in a developing state, failing to acquire the features of adult neurons. They therefore may be transient in nature and destined to undergo cell death at a time when layer formation is completed. A proposed mechanism for this is excessive $\mathrm{Ca}^{2+}$ influx via NMDA receptors (Schwartz et al., 1998; Mienville and Pesold, 1999). This mechanism will be enhanced by the depolar-
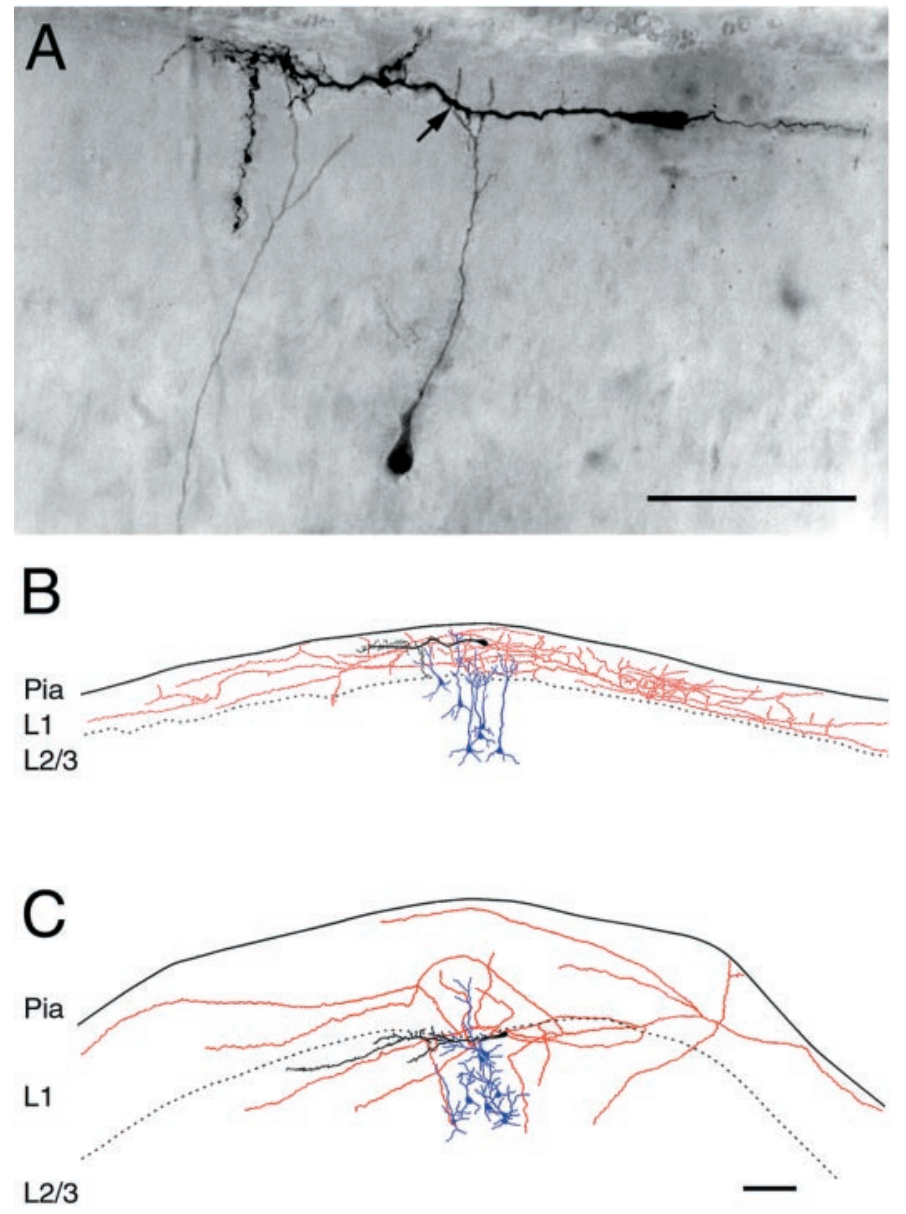

Figure 12. Dye coupling between CR cells and neurons in the underlying cortical layers. $A$, Low-power light microscopic image of a typical CR cell located right beneath the pial surface. A costained pyramidal neuron is visible in layer $2 / 3$. The apical dendrite of this neuron is in close vicinity to the stem dendrite of the CR cell (arrow). Scale bar, $100 \mu \mathrm{m} . B, C$, Camera lucida reconstructions of biocytin-filled CR cells with additional labeling of a cluster of dye-coupled neurons (blue) in layer 2/3. The pyramidal neurons were well stained, whereas the surrounding tissue showed no trace of extracellular dye deposits, suggesting that dye spillover was not the cause for the labeling. Dye coupling was observed in $25 \%$ of cases and may indicate the presence of gap junctional coupling between CR cells and neurons of different cortical layers. The color code of CR cells is the same as in the previous drawings. Scale bar, $100 \mu \mathrm{m}$.

izing GABA $_{\mathrm{A}}$ PSPs (Mienville, 1998). However, the NMDA receptors involved in this process are not only extrajunctional (Mienville and Pesold, 1999) but also located at synaptic sites, as shown here. This may result in a more pronounced $\mathrm{Ca}^{2+}$ influx than by activation via ambient glutamate alone.

\section{A possible functional role of CR cells}

In this study we demonstrate that $\mathrm{CR}$ cells receive dense GABAergic and glutamatergic synaptic input and in turn provide synaptic output preferentially to pyramidal neurons of the underlying cortical layers, thereby constituting an integrative element of an early cortical network. The total population of CR cells provides a dense axonal network that establishes synaptic contacts over a wide range of cortical surface. Thus it appears plausible that synaptic input from CR cells is required to anchor the apical dendrites of their postsynaptic target cells in layer 1, as hypothesized by Marín-Padilla (1998). The interaction between 
CR cells and pyramidal cells may constitute an interface until the latter receive their final afferents in the mature neocortex.

With respect to neocortical organization, CR cells may play a role reminiscent of that of subplate neurons, which provide a scaffold for thalamocortical afferents (McConnell et al., 1989; Friauf et al., 1990; Goodman and Shatz, 1993) with the difference that subplate neurons are transient targets of these afferents, whereas CR cells provide synaptic input to pyramidal neurons. One may speculate that this scaffold is required during early stages of sensory map formation. The secretion of reelin may be one way by which CR cells communicate with other neurons in the developing neocortex. Reelin is a glycoprotein that has been proposed to act as a stop signal for migrating neurons, promote synaptogenesis and neurite outgrowth (D'Arcangelo et al., 1995; Del Rio et al., 1997; Borrell et al., 1999; Rodriguez et al., 2000). This may help to achieve a concerted action of CR cells and their partner neurons during early stages in the development of synaptic circuits.

\section{REFERENCES}

Agmon A, Hollrigel G, O’Dowd DK (1996) Functional GABAergic synaptic connection in neonatal mouse barrel cortex. J Neurosci 16:4684-4695.

Aguiló A, Schwartz TH, Kumar VS, Peterlin ZA, Tsiola A, Soriano E, Yuste R (1999) Involvement of Cajal-Retzius neurons in spontaneous correlated activity of embryonic and postnatal layer 1 from wild-type and reeler mice. J Neurosci 19:10856-10868.

Bayer SA, Altman J (1990) Development of layer I and the subplate in the rat neocortex. Exp Neurol 107:48-62.

Belluardo N, Mudo G, Trovato-Salinaro A, Le Gurun S, Charollais A, Serre-Beinier V, Amato G, Haefliger JA, Meda P, Condorelli DF (2000) Expression of connexin36 in the adult and developing rat brain. Brain Res 865:121-138.

Borrell V, Del Rio JA, Alcantara S, Derer M, Martinez A, D'Arcangelo G, Nakajima K, Mikoshiba K, Derer P, Curran T, Soriano E (1999) Reelin regulates the development and synaptogenesis of the layerspecific entorhino-hippocampal connections. J Neurosci 19:1345-1358.

Bosking WH, Zhang Y, Schofield B, Fitzpatrick D (1997) Orientation selectivity and the arrangement of horizontal connections in the three shrew striate cortex. J Neurosci 17:2112-2127.

Connors BW, Benardo LS, Prince DA (1983) Coupling between neurons of the developing rat neocortex. J Neurosci 3:773-782.

D’Arcangelo G, Miao GG, Chen SC, Soares HD, Morgan JI, Curran T (1995) A protein related to extracellular matrix proteins deleted in the mouse mutant reeler. Nature 374:719-723.

Del Rio JA, Heimrich B, Super H, Borrell V, Frotscher M, Soriano E (1996) Differential survival of Cajal-Retzius cells in organotypic cultures of hippocampus and neocortex. J Neurosci 16:6896-6907.

Del Rio JA, Heimrich B, Borrell V, Förster E, Drakew A, Alcantara S, Nakajima K, Miyata T, Ogawa M, Mikoshiba K, Derer P, Frotscher M, Soriano E (1997) A role for Cajal-Retzius cells and reelin in the development of hippocampal connections. Nature 385:70-74.

Derer P, Derer M (1990) Cajal-Retzius cell ontogenesis and death in mouse brain visualized with horseradish peroxidase and electron microscopy. Neuroscience 36:839-856.

Derer P, Derer M (1992) Development of Cajal-Retzius cells in vivo and in vitro. In: Development of the central nervous system in vertebrates (Sharma SC, Goffinet AM, eds), pp 113-129. New York: Plenum.

Edmunds SM, Parnavelas JG (1982) Retzius-Cajal cells: an ultrastructural study in the developing visual cortex of the rat. J Neurocytol 11:427-446.

Flint AC, Maisch US, Weishaupt JH, Kriegstein AR, Monyer H (1997) NR2A subunit expression shortens NMDA receptor synaptic currents in developing neocortex. J Neurosci 17:2469-2476.

Friauf E, McConnell SK, Shatz CJ (1990) Functional synaptic circuitry in the subplate during fetal and early postnatal development of cat visual cortex. J Neurosci 10:2601-2613.

Frotscher M (1998) Cajal-Retzius cells, reelin, and the formation of layers. Curr Opin Neurobiol 8:570-575.

Goodman CS, Shatz CJ (1993) Developmental mechanisms that generate precise patterns of neuronal connectivity. Neuron 10:77-98.

Gutnick MJ, Prince DA (1981) Dye coupling and possible electrotonic coupling in the guinea pig neocortical slice. Science 211:67-70.

Hestrin S, Armstrong WE (1996) Morphology and physiology of cortical neurons in layer I. J Neurosci 16:5290-5300.

Isaac JT, Nicoll RA, Malenka RC (1995) Evidence for silent synapses: implications for the expression of LTP. Neuron 15:427-434.
Katz LC, Gilbert CD, Wiesel TN (1989) Local circuits and ocular dominance columns in monkey striate cortex. J Neurosci 9:1389-1399.

Kilb W, Luhmann HJ (2000) Characterization of a hyperpolarizationactivated inward current in Cajal-Retzius cells in rat neonatal neocortex. J Neurophysiol 84:1681-1691.

Kilb W, Luhmann HJ (2001) Spontaneous GABAergic postsynaptic currents in Cajal-Retzius cells in neonatal rat cerebral cortex. Eur J Neurosci 13:1387-1390.

Kim HG, Fox K, Connors BW (1995) Properties of excitatory synaptic events in neurons of primary somatosensory cortex of neonatal rats. Cereb Cortex 5:148-157.

Kisvárday Z, Tóth É, Rausch M, Eysel UT (1997) Orientation-specific relationships between populations of excitatory and inhibitory lateral connections in the visual cortex of the cat. Cereb Cortex 7:605-618.

König N, Marty R (1981) Early neurogenesis and synaptogenesis in cerebral cortex. Bibl Anat 19:152-160.

Liao D, Hessler NA, Malinow R (1995) Activation of postsynaptically silent synapses during pairing-induced LTP in CA 1 region of hippocampal slice. Nature 375:400-404.

LoTurco JJ, Kriegstein AR (1991) Clusters of coupled neuroblasts in embryonic neocortex. Science 252:563-566.

Lu S-M, Zecevic N, Yeh HH (2001) Distinct NMDA and AMPA receptor-mediated responses in mouse and human Cajal-Retzius cells. J Neurophysiol 86:2642-2646.

Lübke J, Egger V, Sakmann B, Feldmeyer D (2000) Columnar organization of dendrites and axons of single and synaptically coupled excitatory spiny neurons in layer 4 of the rat. J Neurosci 20:5300-5311.

Luhmann HJ, Prince DA (1991) Postnatal maturation of the GABAergic system in rat neocortex. J Neurophysiol 65:247-263.

Luskin MB, Shatz CJ (1985) Studies of the earliest generated cells of the cat's visual cortex: cogeneration of subplate and marginal zones. J Neurosci 5:1062-1075.

Marín-Padilla M (1978) Dual origin of the mammalian neocortex and evolution of the cortical plate. Anat Embryol (Berl) 152:109-126.

Marín-Padilla M (1990) Three-dimensional structural organization of layer 1 of the human cerebral cortex: a Golgi study. J Comp Neurol 357:554-572.

Marín-Padilla M (1998) Cajal-Retzius cells and the development of the neocortex. Trends Neurosci 21:64-71.

McConnell SK, Gosh A, Shatz CJ (1989) Subplate neurons pioneer the first axon pathway from the cerebral cortex. Science 245:978-982.

Meyer G, Soria JM, Martinez-Galan JR, Martin-Clemente B, Fairen A (1998) Different origins and developmental histories of transient neurons in the marginal zone of the fetal neonatal rat cortex. J Comp Neurol 397:493-518.

Meyer G, Goffinet A, Fairen A (1999) What is a Cajal-Retzius cell? A reassessment of a classical cell type based on recent observations in the developing cortex. Cereb Cortex 9:765-775.

Meyer G, Schaaps JP, Moreau L, Goffinet AM (2000) Embryonic and early fetal development of the human neocortex. J Neurosci 20:1858-1868.

Mienville JM (1998) Persistent depolarizing action of GABA in rat Cajal-Retzius cells. J Physiol (Lond) 512:809-817.

Mienville JM (1999) Cajal-Retzius cell physiology: just in time to bridge the 20th century. Cereb Cortex 9:776-782.

Mienville JM, Pesold C (1999) Low resting potential and postnatal upregulation of NMDA receptors may cause Cajal-Retzius cell death. J Neurosci 19:1636-1646.

Monyer H, Burnashev N, Laurie DJ, Sakmann B, Seeburg PH (1994) Developmental and regional expression in the rat brain and functional properties of four NMDA receptors. Neuron 12:529-540.

Noctor SC, Palmer SL, Hasling T, Juliano SL (1999) Interference with the development of early generated neocortex results in disruption of radial glia and abnormal formation of neocortical layers. Cereb Cortex 9:121-136.

Noctor SC, Flint AC, Weissman TA, Dammerman RS, Kriegstein AR (2001) Neurons derived from radial glial cells establish radial units in neocortex. Nature 409:714-720.

Owens DF, Boyce LH, Davis MB, Kriegstein AR (1996) Excitatory GABA responses in embryonic and neonatal cortical slices demonstrated by gramicidin perforated-patch recordings and calcium imaging. J Neurosci 16:6414-6423.

Parnavelas JG, Edmunds SM (1983) Further evidence that RetziusCajal cells transform to nonpyramidal neurons in the developing rat visual cortex. J Neurocytol 12:863-871.

Parnavelas JG, Papadopoulos GC, Cavanagh ME (1988) Changes in neurotransmitters during development. In: Cerebral cortex (Peters A, Jones EG, eds), pp 177-209. New York: Plenum.

Peinado A, Yuste R, Katz LC (1993a) Gap junctional communication and the development of local circuits in neocortex. Cereb Cortex $3: 488-498$.

Peinado A, Yuste R, Katz LC (1993b) Extensive dye coupling between rat neocortical neurons during the period of circuit formation. Neuron 10:103-114.

Perez-Garcia CG, Gonzalez-Delgado FJ, Suarez-Sola ML, Castro-Fuentes 
R, Martin-Trujillo JM, Ferres-Torres R, Meyer G (2001) Reelinimmunoreactive neurons in the adult vertebrate pallium. J Chem Neuroanat $21: 41-51$.

Rakic P, Caviness VS (1995) Cortical development: view from neurological mutants two decades later. Neuron 14:1101-1104.

Ramón y Cajal S (1891) Sur la structure de l'écorce cérébrale de quelques mammifères. La Cellule 7:125-176.

Retzius G (1893) Die Cajalschen Zellen der Grosshirnrinde beim Menschen und bei Säugetieren. Biol Unters 5:1-9.

Retzius G (1894) Weitere Beiträge zur Kenntnis der Cajalschen Zellen der Grosshirnrinde des Menschen. Biol Unters 6:29-34.

Rodriguez MA, Pesold C, Liu WS, Kriho V, Guidotti A, Pappas GD, Costa E (2000) Colocalization of integrin receptors and reelin in dendritic spine postsynaptic densities of adult nonhuman primate cortex. Proc Natl Acad Sci USA 97:3550-3555.

Rörig B, Klausa G, Sutor B (1996) Intracellular acidification reduced gap junction coupling between immature rat neocortical pyramidal neurones. J Physiol (Lond) 490:31-49.

Schwartz TH, Rabinowitz D, Unni V, Kumar VS, Smetters DK, Tsiola A, Yuste R (1998) Networks of coactive neurons in developing layer 1. Neuron 20:541-552.

Sheng M, Cummings J, Roldan LA, Jan YN, Jan LY (1994) Changing subunit composition of heteromeric NMDA receptors during development of rat cortex. Nature 368:144-147.

Somogyi P, Hodgson AJ (1985) Antisera to $\gamma$-aminobutyric acid. III. Demonstration of GABA in Golgi-impregnated neurons and in conventional electron microscopic sections of cat striate cortex. J Histochem Cytochem 33:249-257.

Stocca G, Vicini S (1998) Increased contribution of NR2A subunit to synaptic NMDA receptors in developing rat cortical neurons. J Physiol (Lond) 507:13-24.

Supèr H, Martinez A, Del Rio JA, Soriano E (1998) Involvement of distinct pioneer neurons in the formation of layer-specific connections in the hippocampus. J Neurosci 18:4616-4626.
Supèr H, Del Rio JA, Martinez A, Perez-Sust P, Soriano E (2000) Disruption of neuronal migration and radial glia in the developing cerebral cortex following ablation of Cajal-Retzius cells. Cereb Cortex 10:602-613.

Takahashi T, Feldmeyer D, Suzuki N, Onodera K, Cull-Candy SG, Sakimura K, Mishina M (1996) Functional correlation of NMDA receptor $\epsilon$ subunits expression with the properties of single-channel and synaptic currents in the developing cerebellum. J Neurosci 16:4376-4382.

Teubner B, Odermatt B, Guldenagel M, Sohl G, Degen J, Bukauskas F, Kronengold J, Verselis VK, Jung YT, Kozak CA, Schilling K, Willecke K (2001) Functional expression of the new gap junction gene connexin 47 transcribed in mouse brain and spinal cord neurons. J Neurosci 21:1117-1126.

Tovar KR, Westbrook GL (1999) The incorporation of NMDA receptors with a distinct subunit composition at nascent hippocampal synapses in vitro. J Neurosci 19:4180-4188.

Verney C, Derer P (1995) Cajal-Retzius neurons in human cerebral cortex at midgestation show immunoreactivity for neurofilament and calcium-binding proteins. J Comp Neurol 359:144-153.

Wang F, Lidow MS (1997) $\alpha_{2 \mathrm{~A}}$-Adrenergic receptors are expressed by diverse cell types in the fetal primate cerebral wall. J Comp Neurol 378:493-507.

Williams K (1993) Ifenprodil discriminates subtypes of the $N$-methyl-Daspartate receptor: selectivity and mechanisms at recombinant heteromeric receptors. Mol Pharmacol 44:851-859.

Yuste R, Peinado A, Katz LC (1992) Neuronal domains in developing neocortex. Science 257:665-669.

Zecevic N, Rakic P (2001) Development of layer I neurons in the primate cerebral cortex. J Neurosci 21:5607-5619.

Zhou FM, Hablitz JJ (1996a) Postnatal development of membrane properties of layer I neurons in rat neocortex. J Neurosci 16:1131-1139.

Zhou FM, Hablitz JJ (1996b) Morphological properties of intracellularly labeled layer I neurons in rat neocortex. J Comp Neurol 376:198213. 